\title{
The Impact of Organizational Envy on Organizational Climate Created among Employees: An Application in Accommodation Enterprises
}

\author{
Aziz Gökhan Özkoç ${ }^{1} \&$ Nurgül Çalışkan ${ }^{1}$ \\ ${ }^{1}$ Faculty of Tourism, Nevsehir Haci Bektas Veli University, Nevşehir, Turkey \\ Correspondence: Aziz Gökhan Özkoç, Faculty of Tourism, Nevsehir Haci Bektas Veli University, 2000 Evler \\ Mah., Merkez Yerleşkesi, 50100 Nevşehir, Turkey. Tel: 90-358-228-1130. E-mail: aziz.ozkoc@gmail.com
}

Received: October 29, 2014

Accepted: November 13, 2014 Online Published: December 20, 2014

doi:10.5539/ijbm.v10n1p40

URL: http://dx.doi.org/10.5539/ijbm.v10n1p40

\begin{abstract}
Expression of individuals' emotional intelligence is an important factor to reach success in organizational life as well as daily life. Positive or negative emotions of employees have the potential to affect the organizational climate created through their relationship between each other in a positive or negative way. In this study, the impact of envy -which is a new issue in organizational behavior literature- on organizational climate, which has an important role in organizations' realization of their main goals by ensuring intra-organizational harmony, was examined. At the end of this empirical study held in accommodation enterprises in Kuşadası which is a popular tourism destination in Turkey, an inverse, not-strong, significant relation was discovered between envy among employees and perception of organizational climate. Through the regression analysis, it was seen that the independent variable organizational envy could explain $9.1 \%$ of the change in the dependent variable organizational climate. At first glance, this proportion could be regarded as low but that envy reached this percent among many variables which may affect organizational climate displays the importance of the level of its impact.
\end{abstract}

Keywords: envy, organizational climate, accommodation enterprises

\section{Introduction}

Human skills are gaining more importance in commercial arena in which the organizations struggle for their existence based on maximum efficiency/productivity. This situation led to different approaches based on human resource both in industry and academia dimensions. Today managers do not consider "human" factor merely as a factor of production but they tend to define it as a psycho-social reality/fact. Emotional factors have an important place in the behavioral tendencies of human which is a psycho-social creature. For this reason, an organizational setting cannot be regarded as an environment independent from emotions. Positive and negative emotions of the employees as a member of an organization will take an important place in the creation of a work environment that makes organizations more productive/efficient.

Each employee in an organization has his/her own personality characteristics, emotions, norms, and values. The interaction between these unique qualities and organizations structure, goals, and work relations creates "organizational climate". Organizational climate is broadly the dominant atmosphere in the organization. Behavioral patterns, approaches and feelings that characterize working life (İşcan \& Karabey, 2007, p. 182), in short, psychological environment of the organization could be defined as organizational climate. While positive emotions among employees play an important role in organizations' reach to success and in the development of positive behaviors such as higher motivation, better performance, organizational citizenship, organizational trust, and loyalty by affecting the organizational climate that is created by the employees' organizational attitudes and behaviors (Denison, 1996) in a positive way, negative feelings such as fear, hatred, grudge, jealousy, and intolerance may cause negative behaviors that may weaken the organization such as non-productivity, stress, burnout, mobbing, job leave, and etc. by affecting organizational climate in a negative way.

Envy, which has not attracted enough attention among the emotions which have been examined in the discipline of management, is also one of the negative feelings that may lead to these negative behaviors by affecting 
organizational climate in a negative way. The purpose of this study is to discover the relation between envy, which is one of the negative feelings in an organizational setting, and organizational climate created by the employees' organizational attitudes and behaviors both theoretically and empirically and to determine the impact of envy on organizational climate. The research is important since it gives the capability to make recommendations for diminishing or preventing the negative consequences of envy by theoretically expressing how and why the relation between envy and organizational climate occurs and empirically discovering the impact of envy on organizational climate. Moreover, it is anticipated that this research might fill the gap in international management literature and contribute to the literature that contains few studies on the concept of envy.

\section{Organizational Envy}

Envy is described as the state of willing to own what the others own, comparing the qualifications, success, and financial opportunities of others with one's own and in the end, feeling great jealousy of others (Parrott \& Smith, 1993; Pines, 1998; Anderson, 2002; Kim \& Hupka, 2002, Klein, 1975). The main difference between envy and jealousy is that envy contains two people unlike jealousy which contains three people. The focus of envy is either an object or a property. The focus of jealousy is, on the other hand, a third person who is perceived as a threat to the present relation (Friday, 2000; Salovey \& Rodin, 1984). In other words, envy directly focuses on the object of love itself and wants to obtain its good properties while jealousy aims to obtain the object of love and eliminate the competitor (Klein, 1975). When the studies which aim to explain the concept of envy are considered in total, envy can be described as one's willingness to obtain the qualities like personal success and property that another person has or the wish that the other person would lack what he/she has and inner conflict caused by this wish.

There are some factors that cause people to feel envy. These factors can be grouped into two categories (a) the persons' characteristic tendency towards envy (b) situational factors that lead the person to this feeling. Characteristic tendency towards envy is caused by the lack of self confidence and researches of development psychology shows that beliefs, values, and attitudes gained during childhood affect the individual's behavior in work environment. Therefore, this situation indicated that personal life experiences gained prior to being employed for a position might affect the individual's tendency towards the feeling of envy (Cooper \& Payne, 1988; Dogan \& Vecchio, 2001). The situational factors in the organization that lead the individual to the feeling of envy are, on the other hand, competition, strategic downsizing, reengineering, cultural differentiation, performance evaluation, human resources applications like unfair systems of reward/punishment and promotion.

\subsection{Relational Studies that Examine Envy in Organizations}

A limited number of studies were done on envy in an organizational setting till today and these studies were based on different methods and theories from each other. These studies can be grouped according to three approaches. The first one is the quantitative studies that focus on the person who envies through social psychology by an individual based perspective and use self-report survey method in which the individual evaluates himself/herself. In this context, the studies of Duffy \& Shaw (2000), Schauberk \& Lam (2004), Vecchio (1995, 2000, 2005), Cohen-Charash \& Mueller (2007), Khan \& Quaratulain (2009) and Kim, O'Neil \& Cho (2010) focused on the existence and outcomes of envy which is triggered by situational factors.

Vecchio (2005) approached the feeling of envy from the perspective of the envier and the envied and revealed a significant relation between the feeling of envy and leader-member interaction, job satisfaction, service time, and reward systems in the organization. Similarly, Kim, O'Neil and Cho (2010) showed that employees who had lower interaction with their managers, in other words who stayed in outer group in the result of leader-member interaction, had more tendency towards the feeling of envy when compared to the members of the inner group. They also stated that feeling of envy had a mediator role in the relation between leader-member interaction and organizational citizenship behavior.

Cohen-Charash and Mueller (2007) revealed that high level of tendency towards envy and low level of organizational fairness/justice in an organizational environment resulted in harmful behavior in the organization. The study conducted by Khan and Quaratulain (2009) determined that perception of organizational justice played a mediator role in the relation between employees' tendency to the feeling of envy and their harmful behavior towards colleagues and the organization. Unlike Cohen-Charash and Mueller's (2007), the findings of that study shows that tendency of the employees, who perceive this situation as a threat, to envy rise as employees' distribution justice perception, which is related to gains in the organization such as wages and promotions, increase thus their harmful behavior towards colleagues increases. In the same study, it is also stated that employees' harmful behavior towards the organization such as work hindrance, slowdown, and lateness and 
their tendency to envy increase as their perception of transactional justice, which is related to fairness of the methods used in distribution channels, increases.

The second approach which has a psychoanalytical view is used in qualitative studies based on Melanie Klein and Jacques Lacan's theories. Main goal of this approach is to emphasize that envy causes organizational dysfunctions and seriously harms the system. These studies are based on case study method and many of them are reconstructed after in depth interviews by the inspiration of psychoanalytic themes like Shakespeare's Othello. While Halton (1994), Kets de Vries \& Miller (1984), Mouly \& Sankaran (2002), Schlapobersky ( 1994), and Stein's (1997, 2000a, 2000b, 2005) studies on envy are based on Melanie Klein's theory, Benedicte Vidaillet's (2007) study is the only one based on Jacgues Lacan's theory. Vidaillet's study on envy is also unique because of being the only term case study that used diary method. The third one is social constructivism approach which is used in order to reveal envy in an organizational setting. The only study based on this approach was made by Patient, Lawrence and Maitlis (2003). These researchers attempted to analyze envy in work environment through discourse analysis method by using three passages from Richard Russo's novel "Straight Man" which was published in 1997.

\section{The Relation between Organizational Envy and Organizational Climate and Determination of Research Hypothesis}

Organizational climate includes employees' perceptions of the work and organization, distinct features of an organization, and the nature of the employees' relations between each other and with managers while performing their jobs (Churchill et al., 1976: 324). Therefore, the climate of an organization, which is an open system, might be affected by both external factors and personal and perceptional features of individuals in the organization.

As one of the personal and perceptional features of the employees in the organization, envy is a feeling at a level that might have the potential to affect organizational climate. Envy which could be generated through some factors among employees may contain some malevolence in addition to anger and may result in serious outcomes such as violence, mobbing, gossip, non-productivity, and increased rates of turnover by negatively affecting the organizational climate which is one of the major factors that could lead organizations to success. For instance, fear for dismissal may cause the individual perceive his/her colleagues as a threat and result in creating envy among employees. Therefore, the employee may intentionally make an attempt to prevent his/her colleague's success; may make changes in his/her colleague's reports or intentionally relay customer wishes falsely (Dogan \& Vecchio, 2001). This does not only affect the colleague's performance but might also cause failures in the organizational processes and harm stakeholders by negatively affecting employees' perception of organizational climate. In conclusion, it is anticipated that this toxic feeling, which is widespread in organizational settings, may negatively affect relations between employees by causing reactional approach to the work, person, or organization and may therefore harm organizational climate, which is one of the major factors in a company's reach its major goals by ensuring intra-organizational coherence. Vice versa, lower levels of envy might strengthen organizational climate which is a sign of healthy work environment. The following hypothesis was developed in the scope of this research in order to test this given theoretical content via statistical methods.

H1: Envy among employees affects work relations-based organizational climate, reversely.

\section{Research Method}

Survey method was used in order to test $\mathrm{H} 1$ hypothesis which was developed to measure the probable impact of envy in organizations on organizational climate generated among employees. The survey was applied to employees who worked in various departments in accommodation enterprises.

\subsection{Universe of the Research and Sample Size}

Survey data was collected in 2014. Research was conducted on 3, 4, and 5-star accommodation enterprises in Kuşadası region which is one of the elite tourism destinations in Turkey and one of the most frequently visited places with approximately as much as 1,5 million tourists a year and employees in various departments in accommodation enterprises were attempted to be contacted. While applying the survey, managers of accommodation enterprises in the region were contacted directly and survey forms were delivered to the enterprises who agreed to participate in the survey, then these forms were collected after a short period of time. $163(43.4 \%)$ of the participants were the employees of 5-star accommodation enterprises, $118(31.4 \%)$ were 4-star, and 95 (25.3\%) were employees of 3-star accommodation enterprises.

There are seven 5-star accommodation enterprises with a total of 3955 beds, twenty-five 4-star accommodation enterprises with 7155 beds, and eleven 3-star accommodation enterprises with 1826 beds; namely 43 accommodation enterprises in total according to the data provided by Governing Organization for Culture and 
Tourism of the Province of Aydın (geka.org.tr, 2014), to where Kuşadası Tourism Destination was dependent. When the current tourism statistics were examined, it can be observed that no data on the employees of accommodation enterprises were included. For this reason, "number of employees per bed" was calculated by considering the literature in order to determine size of the research universe. Ağaoğlu (1992:114) determined "employee per bed" numbers in Turkey as 0,36 for 3-star accommodation enterprises, 0,38 for 4-star ones, and 0,59 for 5 -star ones. Based on these numbers, it was estimated that 658 employees who worked for 3-star enterprises, 2719 employees for 4-star enterprises, and 2334 for 5 -star enterprises (5711 employees in total) in Kuşadası constituted the universe of research. 360 employees were determined to be the sample of the research through the calculations taking acceptable sample bias as $\pm 0,05$ and significance level as $(\alpha) 0,05$ (Yazıcığlu and Erdoğan, 2004, pp. 49-50).

490 survey forms in total were handed to the accommodation enterprises in order to reach sufficient sample size. Of these, 376 statistically usable forms were collected. Namely, return rate was more than total sufficient sample size.

As the sampling method of the research, "convenience sampling" method was used. Base for this method is to include everybody who responds to the survey form. The ideal respondent is the one who can be reached most easily. It is continued to find respondents till reaching the desired sample size (Altunış1k et al, 2007, p. 132).

\subsection{Preparation of Survey Form and Application of the Survey}

The survey form consists of two parts. In the first part, it is aimed to measure organizational envy and perception of organizational climate among employees. In the second part, close-ended questions were prepared in order to determine personal information of employees in accommodation enterprises.

Scale used to measure the level of envy felt by accommodation enterprise employees was developed by Vecchio (2005) and it consisted of 8 statements in total. Organizational Climate Description Questionnaire developed by Halpin and Croft (1963) was adapted, which consisted of 12 statements in total, in order to measure the perception of organizational climate among employees. Organizational Climate Description Scale measures organizational climate perceived by employees from the point of managers and employees/work relations. Since this study considered the organizational climate among employees as a variable, only the work relations dimension of the scale which consisted of 12 statements was included in the survey form.

In order to measure the variables of organizational envy and organizational climate, respondents were asked to indicate their level of agreement with the statements developed as 5-point Likert scale. The statements in the Likert scale were as follows: "Totally disagree (1)", "Slightly agree (2)", "Reasonably agree (3)", "Substantially agree (4)", and "Totally agree (5)".

In the second part of the survey form which was developed as a tool of data collection, 6 close-ended questions were asked in order to determine the features of employees participated in the survey (age, education level, gender, department, work period in the industry, and work period in the company).

Reliability levels of the scales used in the study were measured to be in high levels as expected. While the reliability coefficient (Cronbach's alpha value) of 8 statements related to organizational envy were 0,75 , reliability coefficient of 12 statements constituted organizational envy was calculated as 0,76 . In order to ensure the validity of the scale used, utmost attention was given to prevent the statements from losing their original meanings in translation process and detailed evaluations were made together with experts (such as psychologists, sociologists, management scientists, and etc.) during pretests.

\section{Findings of the Research}

Data gathered through the survey were tested via appropriate statistical methods and again appropriate methods were used for the documentation of these data. In this part, all data gathered through survey study were evaluated and interpreted beginning with the demographic features of participants till the testing of hypotheses.

\subsection{Findings and Evaluations on Demographic Features of Participants}

Figures on demographic features of 3, 4, and 5-star hotel employees which constituted the sample of the research were detailed in Table 1.

As can be seen in Table 1, 55,9 \% (n:210) of the 376 participants were male and 44, $1 \%$ (n: 166) were female employees. 55,1\% (n:207) of the participants were between the ages of 21-30, 24,2 \% (n: 91) were between $31-40,15,4 \%$ (n:58) were 20 years old or younger while 41 years old or older participants were rare (5,3\%, n: 20). When examined in terms of education level, it can be seen that majority (71\%) of participants were high school graduates (n: 140) or had a bachelor's degree (n: 127). 
Table 1. Statistics on demographic and personal features of participants

\begin{tabular}{|c|c|c|c|}
\hline Variable & Group & Number (f) $n$ & Percentage $(\%)$ \\
\hline \multirow[t]{2}{*}{ Gender } & Male & 210 & 55,9 \\
\hline & Female & 166 & 44,1 \\
\hline \multirow[t]{5}{*}{ Age } & 20 or younger & 58 & 15,4 \\
\hline & $21-30$ & 207 & 55,1 \\
\hline & $31-40$ & 91 & 24,2 \\
\hline & $41-50$ & 17 & 4,5 \\
\hline & 51 or older & 3 & 0,8 \\
\hline \multirow[t]{5}{*}{ Level of Education } & Primary School & 52 & 13,8 \\
\hline & High School & 140 & 37,2 \\
\hline & Diploma Degree & 51 & 13,6 \\
\hline & Bachelor's Degree & 127 & 33,8 \\
\hline & Graduate Degree & 6 & 1,6 \\
\hline \multirow[t]{6}{*}{ Working Period in Tourism Industry } & Less than 1 year & 67 & 17,8 \\
\hline & $1-5$ years & 81 & 21,5 \\
\hline & $6-10$ years & 102 & 27,1 \\
\hline & $11-15$ years & 73 & 19,4 \\
\hline & $16-20$ years & 46 & 12,3 \\
\hline & 21 years or over & 7 & 1,9 \\
\hline \multirow[t]{7}{*}{ Working Period at current hotel } & Less than 1 year & 118 & 31,4 \\
\hline & $1-5$ years & 101 & 26,9 \\
\hline & $6-10$ years & 106 & 28,2 \\
\hline & $11-15$ years & 43 & 11,4 \\
\hline & $16-20$ years & 7 & 1,9 \\
\hline & 21 years or over & 1 & 0,3 \\
\hline & Total & 376 & 100 \\
\hline
\end{tabular}

In Table 1, it can also be seen that $27.1 \%$ (n:102) of the participants had served in the tourism industry for 6-10 years, $21.5 \%$ (n: 81) served for 1-5 years, 19,4\%, (n:73) served for 11-15 years, and 12,3\% (n:46) served for 16-20 years. While the proportion of participants who had been working in the industry for less than 1 year is $17,8 \%$ (n:67), those who had been working for more than 21 years constituted $1,9 \%$ (n:7). When the participants' working period of time in their current companies were examined, it can be seen that $31,4 \%(\mathrm{n}: 118)$ of the participants had been working there for less than 1 year, $28,2 \%(\mathrm{n}: 106)$ for $6-10$ years, and 26,9\% (n:101) $1-5$ years. $13.6 \%$ (n:51) of the participants stated that they had been working for their current company for more than 11 years.

\subsection{Findings on Employees' Perception of Organizational Envy and Organizational Climate}

Values on two major variables which are the subject of the research hypothesis are shown in Table 2. First, arithmetic means and their standard deviations of the participants' responses to statements which explains organizational climate created among employees and organizational envy is given. Arithmetic mean of organizational envy variable was calculated as 2 and the mean of organizational climate created among employees was calculated as 3,6. Based on the data in hand, it could be stated that participants' intra-organizational envy feelings were low and their perceptions of organizational climate created among employees were higher than 3 which was the median value. 
Table 2. Values on organizational climate and organizational envy variables

\begin{tabular}{|c|c|c|c|c|c|}
\hline VARIABLES & $\mathbf{N}$ & AO & $\begin{array}{l}\text { Std. } \\
\text { Deviation }\end{array}$ & t-value & p-value \\
\hline Organizational Envy & 376 & 2 & 0,81 & $-23,803$ & $0,00 * *$ \\
\hline Organizational Climate Created Among Employees & 376 & 3,6 & 0,69 & 17,025 & $0,00 * *$ \\
\hline
\end{tabular}

Note. ** Value is significant at 0,01 level $(\mathrm{p}<0,01)$.

At the second phase, one-sample t-test was applied to each variable. One-sample t-test determines the level of difference of arithmetic mean of the variables examined in the research from 3 (Reasonably agree) which was median value of the scale. 0,01 was used as the level of statistical significance in the tests applied. Thus, it could be stated that arithmetic means of statements related to organizational envy and organizational climate variables were significantly different from the point "Reasonably agree". These differences were, as can also be understood from $t$ values, significant as being lower than median value in organizational envy and higher than median value in perception of organizational climate. It could be observed that most participants selected the options of "Totally disagree" and "Slightly agree" for the statements that measured the perception of organizational envy. This exhibits that envy created among employees in the organizations was in quite a low level. "Reasonably agree", "Substantially agree" and "Totally agree" options were mostly selected among the statements that measured organizational climate created among employees. These statements had a value greater than median value of scale but it was observed that measurements on the perception of organizational climate created among accommodation enterprise employees included in the research were not of ideal results.

\subsection{Relation and Hypothesis Tests}

At this phase, regression and correlation analyses were conducted to measure the interrelation of current variables (organizational envy and organizational climate created among employees) in order to test the hypothesis developed based on the theoretical background of the research.

First, a correlation analysis was conducted to define the direction and level of the relation between two variables. Correlation analysis is a technique of analysis which is made to determine the level of relation or interdependency between two variables which have been measured in interval or ratio level. The relation which is aimed to measure via correlation analysis is related to the linear part of the relation between variables. The correlation coefficient calculated through correlation analysis is shown with $r$ and can take a value between -1 and $+1(-1 \leq \mathrm{r}<+1)$. While the sign ( + or -$)$ of correlation coefficient $(r)$ shows the relation's direction as direct or inverse, greatness of the coefficient shows the level of relation between variables. If the value of a variable increases or decreases regularly, as the value of another variable increases, the relation between these two variables is linear (Altunışık et al., 2012: 228). In this research, relations between organizational envy and perception of organizational climate created among employees were examined via correlation analysis (see Table $3)$.

Table 3. Findings of correlation and regression analyses which examine the relation between organizational envy and organizational climate created among employees

\begin{tabular}{|c|c|c|c|}
\hline INDEPENDENT VARIABLE & BETA & $\mathbf{T}$ & SIG. (P) \\
\hline Organizational Envy &,- 302 & $-6,118^{* *}$ &, 000 \\
\hline $\mathbf{r}$ & \multicolumn{3}{|c|}{$-0,302 * *(p=0,00)$} \\
\hline $\mathbf{F}$ & \multicolumn{3}{|c|}{$37,430 * *$} \\
\hline $\mathbf{R}$ & \multicolumn{3}{|l|}{,302 } \\
\hline $\mathbf{R}^{2}$ & \multicolumn{3}{|l|}{,091 } \\
\hline B & \multicolumn{3}{|l|}{4,112} \\
\hline
\end{tabular}




$$
\begin{gathered}
\text { Organizational Climate }=f(\text { Organizational Envy }) \\
Y=B 0+\text { B1.Xoe } \\
Y=4,112+(-0,302) . \text { Xoe }
\end{gathered}
$$

Through the correlation analysis conducted, it was determined that there was a significant and non-strong relation between organizational envy and perception of organizational climate created among employees. The direction of the relation between these two variables were negative $(r=-0,302, p=, 000)$. Namely, as the level of organizational envy among employees decrease, perception of organizational climate strengthens.

Results of regression analysis, which examines the relations between two variables, conducted to test the main hypothesis of the research are exhibited in Table 3. Regression analysis is a statistical method conducted with the aims such as examining the existence of a relation between a dependent metric variable and one or more independent metric variable(s), determining the level of relation, stating the relation mathematically, and forecasting. In this method of analysis, a mathematical model is used to explain the relation between two (simple regression) or more variables (multiple regression) (Altunış1k et al., 2012).

In order to test the main hypothesis of the research, one variable regression (simple regression) analysis that examined the relation between dependent variable (organizational climate) and independent variable (organizational envy) was conducted. Through this analysis, a line equation that represented the linear relation between dependent and independent variables was formulated.

Prerequisite for simple regression analysis is that there has to be relation between variables. Through the correlation analysis conducted, it was found that there was an inverse linear relation between organizational climate and organizational envy (r: -302). Thus, the following model could be formed.

$$
\tilde{Y}_{\dot{I}}=\beta_{0}+\beta_{1} X_{\dot{I}}
$$

Y: Organizational Climate (dependent variable);

$\mathrm{X}_{\mathrm{I}}$ : Organizational Envy (independent variable).

In table 3 , it can be seen that the developed regression model is significant at $99 \%$ reliability level $(p=0,000<$ $\alpha: 0,01)$ and organizational envy makes a statistically significant contribution to the explanatorines of the model $(\mathrm{t}:-6,118, \mathrm{p}=0,000<\alpha: 0,01)$. Organizational envy could explain the $9,1 \%\left(\mathrm{R}^{2}: 0,91\right)$ of the change in organizational climate perception. It could be stated that a one unit increase in organizational envy score will result in a $0,302\left(\beta_{1}\right)$ decrease in organizational climate perception score.

As can be inferred from the statistical data collected, regression model developed to test $\mathrm{H}_{1}$ hypothesis confirms the hypothesis. Envy among employees negatively affects organizational climate perception based on work relations. However, it can be understood from the $\mathrm{R}^{2}$ value $(0,091)$ calculated through regression analysis that aforementioned impact is not strong.

\section{Conclusion and Recommendations}

Via the survey study conducted, desired statistical data to measure how much the envy that could be occurred in organizations based on work relations could affect the continuation of a healthy work environment were reached. First of all, it could be seen that envy occurred among employees of accommodation enterprises involved in the research was in quite low levels. Thus, the possibility that harmful behavioral tendencies that could be led by envy would occur in the accommodation enterprises where social relations are intense is low. That those sorts of behaviors which could even reach up to physical violence not occur would support work relations based organizational climate to be built on healthy basis.

Some owned norms and values directly affect sales volume of the companies in accommodation industry which is a branch of services industry. For this reason, organizational culture which is described as the total of employees' shared norms and values has a special importance for accommodation enterprises. Organizational climate is a concept that expresses healthy work relations established as an outcome of organizational culture. Higher levels of organizational climate discovered in accommodation enterprises involved in the study indicate that a healthy work environment has been established among employees. However, when arithmetic mean of organizational climate variable $($ A. $0=3,6)$ is examined, it is observed that employees responded medium levels of agreement to some statements. This shows the requirement that qualities that constitutes organizational climate such as solidarity, sharing, and cooperation should be strengthened more via organizational culture.

The main focus point of this study is the extent of cause-effect relation between a desired low level of envy among employees and a higher than average level of organizational climate perception. Research hypothesis 
developed to test the relation between two variables was accepted through statistical data revealed. In other words, envy among employees negatively affects the perception of organizational climate. This reverse effect was in favor of the accommodation enterprises involved in the research. Low levels of envy among employees of the accommodation enterprises strengthen the organizational climate. Consequently, if a manager wants cohesion, coordination, and solidarity among his/her staff, he/she should avoid decisions which could cause envy in the organization. Although there are some factors that a manager cannot influence such as the employees' personal tendencies to envy, a healthy reward-punishment system established in an organization might prevent envy.

Employees' might have tendency to harm each other psychologically and physically in case of higher levels of envy in an organization. Although this sort of a risk was yet low in accommodation enterprises involved in the research, unfavorable occurrences in work relations which might happen in a short period of time could trigger envy. Work life is always prone to uncertainties which could occur either in or out of the organization. In addition to taking precautions to prevent envy, managers should also take necessary precautions to manage possible envy among employees in order not to let it harm organizational climate. Scientific studies should be conducted on alternative techniques to be applied by managers to prevent envy in organizations from reaching to a level that harms organizational climate. It seems probable that these studies could be based on "conflict management" in organizational behavior literature.

Another point to be discussed about the interrelation between envy and organizational climate is the result related to the level of impact obtained through regression analysis. Data in hand shows that the independent variable organizational envy could explain only $9,1 \%$ of the change in the dependent variable organizational climate. Although this level of impact seems quite low at first glance, it could be assumed that it is even quite high when the extensive role of the variables in the organization is considered. Organizational climate strengthens or weakens under the influence of many concepts of organizational behavior literature. Many variables such as organizational justice (Ehrhart, 2004), organizational loyalty (Illeez,2012), organizational citizenship (Dinçer, 2013), organizational stress (Küçüksarı, 2012), employee motivation (Özkul, 2013), job satisfaction (Pritchard \& Karasick, 1973), conflict (Nordin et al., 2014), communication (Gül, 2012), and intraorganizational networking/grouping have the potential to be direclty interrelated with organizational climate among employees. Among these variables, envy has an average of $9 \%$ impact on organizational climate and this proportion indicates the absolute importance of envy among other variables that affect envy.

Just like organizational climate created among employees, many other variables which have the potential to affect envy are waiting to be tested by quantitative data. Similarly, it is predicted that organizational envy does not only affect organizational climate but it could also affect many other variables such as trust, justice, and communication. More quantitative studies in which envy is considered dependent or independent variable could enable better interpretation of work relations. Based on the literature review made, a need for more studies on the concepts that could affect organizational climate among employees was observed.

Through this research, it was observed that there was a great gap in the literature on the measurement of envy in organizations. During the application of questionnaire, it was discovered that some statements were not understood clearly and that they were not in enough detail. For this reason, more scientific researches should be conducted in order to strengthen organizational envy scale and the concept of organizational envy should be examined in scientific arena in more detail through new scales on different samples.

\section{References}

Ağaoğlu, O. K. (1992). İşgücünü verimli kullanma tekniklerinin turizm sektörüne uygulanması. Verimlilik Dergisi, 110-121.

Altunışık, R., Coşkun, R., Bayraktaroğlu, S., \& Yıldırım, E. (2012). Sosyal Bilimlerde Araştırma Yöntemleri. Sakarya: Sakarya Yayıncılık.

Anderson, R. E. (2002). Envy and Jealousy. American Journal of Psychotherapy, 56(4), 455-480. http://dx.doi.org/10.1300/J035v01n04_04

Churchill, G. A., Ford, N. M., \& Walker, O. C. (1976). Organizational climate and job satisfaction in the salesforce. Journal of Marketing Research, 13, 323-332.

Cohen-Charash, Y., \& Mueller, J. (2007). Does perceived unfairness exacerbate or mitigate interpersonal counterproductive behaviors related to envy? Journal of Applied Psychology, 92(3), 666-680. http://dx.doi.org/10.1037/0021-9010.92.3.666

Cooper, C., \& Payne, R. (1988). Causes, coping and consequences of stress a t-work. Chichester, UK. 
Denison, D. R. (1996). What is the difference between organizational culture and organizationalclimate? A native's point of view on a decade of paradigm wars. The Academy of Management Review, 21(3), 619-654. http://dx.doi.org/10.5465/AMR.1996.9702100310

Dinçer, E. (2013). Örgüt iklimi ve örgütsel vatandaşlık davranışı arasındaki ilişki: Bir kamu kurumunda araştırma. Yüksek lisans tezi, Gazi Üniversitesi Sosyal Bilimler Enstitüsü, Ankara.

Dogan, K., \& Vecchio, R. P. (2001). Managing envy and jealousy in the workplace. Compensation and Benefits Review, 33, 57-64. http://dx.doi.org/10.1177/08863680122098298

Duffy, M., \& Shaw, J. (2000). The salieri syndrome: Consequences of envy in groups. Small GroupResearch, 31(1), 3-22. http://dx.doi.org/10.1177/104649640003100101

Ehrhart, M. G. (2004). Leadership and procedural justice climate as antecedents of unit-level organizational $\begin{array}{lllll}\text { citizenship } & \text { behaviors. } & \text { Personnel } & \text { Psychology, } & \text { 57(1), }\end{array}$ http://dx.doi.org/10.1111/j.1744-6570.2004.tb02484.x

Friday, N. (1994). Jealousy. NY: The New York Times Company.

Gül, Ö. (2012). Örgütsel İklim ve İletişim İklimi Arasındaki Etkileşim: Omu Vakfi İşletmelerinde Bir Araştırma. Yüksek lisans tezi, Dumlupınar Üniversitesi Sosyal Bilimler Enstitüsü, Kütayha.

Halpin, A. W., \& Croft, D. B. (1963). The organizational climate of schools. Chicago: Midwest Administration Center of the University of Chicago.

Halton, W. (1994). Some unconscious aspects of organizational life: Contributions from psychoanalysis. London Routledge, 11-18.

İlleez, Z. (2012). Örgüt İkliminin iş görenlerin örgütsel bağllllklarına etkisi: Konaklama işletmelerinde bir uygulama. Yüksek lisans tezi, Gazi Üniversitesi Eğitim Bilimleri Enstitüsü, Ankara.

İşcan, Ö. F., \& Karabey, C. N. (2007). Örgüt iklimi ile yeniliğe destek algısı arasındaki iillişki.Gaziantep Üniversitesi Sosyal Bilimler Dergisi, 2(2), 180-193.

Kets de Vries, M. F., \& Miller, D. (1984). The neurotic organization: Diagnosing and changing counterproductive styles of management. San Francisco, CA: Jossey-Bass.

Khan, A. K., Peretti, J. M., \& Quratulain, S. (2009). Envy and counterproductive work behaviors: is more fairness always preferred? 20th AGRH Conference (9th-11th Septembre 2009, Toulouse, France) of the French-speaking HR/OB Research Scholarly Association.

Kim, H. J., \& Hupka, R. B. (2002). Comparison of associative meaning of the concepts of anger, envy, fear, romantic jealousy, and sadness between English and Korean. Cross-Cultural Research, 36(3), 229-255. http://dx.doi.org/10.1177/10697102036003003

Kim, H., O'Neil, J. W., \& Cho, H. (2010). When does an employee not help coworkers? The effect of leader-member exchange on employee envy and organizational citizenship behavior. International Journal of Hospitality Management, 29, 530-537. http://dx.doi.org/10.1016/j.ijhm.2009.08.003/

Klein, M. (1975). Envy and gratitude and other works 1946-1963. New York: Vintage.

Küçüksarı, Ş. (2012). Örgüt iklimi ile stres arasındaki ilişkinin belirlenmesine yönelik bir araştırma. Yüksek lisans tezi, Dumlupınar Üniversitesi Sosyal Bilimler Enstitüsü, Kütahya.

Mouly, V. S., \& Sankaran, J. K. (2002). The enactment of envy within organizations. Journal of Applied Behavioral Science, 38(1), 36-57. http://dx.doi.org/10.1177/0021886302381003

Nordin, S., Sivapalan, S., Bhattacharyya, E., Ahmad, H., \& Azrai, A. (2014). Organizational communication climate and conflict management: communications management in an oil and gas company. Procedia-Social and Behavioral Sciences, 109(8), 1046-1058. http://dx.doi.org/10.1016/j.sbspro.2013.12.587

Özkul, Y. (2013). Örgüt ikliminin motivasyon üzerine etkisi: Bir uygulama. Yüksek lisans tezi, Marmara Üniversitesi Sosyal Bilimler Enstitüsü, İstanbul.

Parrot, W. G., \& Smith, R. H. (1993). Distinguishing the experience of jealousy and envy. Journal of Personality and Social Psychology, 64, 906-920. http://dx.doi.org/10.1037/0022-3514.64.6.906

Patient, D., Lawrence, T., \& Maitlis, S. (2003). Understanding workplace envy through narrative fiction. Organization Studies, 24(7), 1015-1044. http://dx.doi.org/10.1177/01708406030247002 
Pines, A. M. (1998). Romantic Jealousy: Causes, symptoms, cures. NY: Routledge.

Pritchard, R. D., \& Karasick, B. W. (1973). The effects of organizational climate on managerial job performance and job satisfaction. Organizational Behavior And Human Performance, 9, 126-146. http://dx.doi.org/10.1016/0030-5073(73)90042-1

Russo, R. (1997). Straight Man. NY: Rondom House.

Salovey, P., \& Rodin, J. (1984). Some antecedents and consequences of social comparison jealousy. Journal of Personality and Social Psychology, 47(4), 780-792. http://dx.doi.org/10.1037/0022-3514.47.4.780

Schaubroeck, J., \& Lam, S. (2004). Comparing lots before and after: Promotion rejectees' invidious reactions to promotees. Organizational Behavior and Human Decision Processes, 94, 33-47. http://dx.doi.org/10.1016/j.obhdp.2004.01.001

Schlapobersky, J. (1994). The language of the group: Monologue, dialogue and discourse in group analysis. London: Routledge.

Stein, M. (1997). Envy and leadership. European Journal of Work and Organizational Psychology, 6(4), 453-465. http://dx.doi.org/10.1080/135943297399033

Stein, M. (2000a). After Eden: Envy and the defences against anxiety paradigm. Human Relations, 53(2), $193-212$.

Stein, M. (2000b). The risk taker as shadow: A psychoanalytic view of the collapse of Barings Bank. The Journal of Management Studies, 37(8), 1215-1227. http://dx.doi.org/10.1111/1467-6486.00222

Stein, M. (2005). The Othello conundrum: The inner contagion of leadership. Organization Studies, 26(9), 1405-1419. http://dx.doi.org/10.1177/0170840605055339

Vecchio, R. P. (1995). It's not easy being green: Jealousy and envy in the workplace. Research In Personnel and Human Resources Management, 13, 201-244.

Vecchio, R. P. (2000). Negative emotion in the workplace: Employee jealousy and envy. InternationalJournal of Stress Management, 7(3), 161-179. http://dx.doi.org/10.1023/A:1009592430712

Vecchio, R. P. (2005). Explorations in employee envy: Feeling envious and feeling envied. Cognitionand Emotion, 19(1), 69-81. http://dx.doi.org/10.1080/02699930441000148

Vidaillet, B. (2007). Lacanian theory's contribution to the study of workplace envy. Human Relations, 60(11), 1669-1700. http://dx.doi.org/10.1177/0018726707084304

Yazıcıŏlu, Y., \& ve Erdoğan, S. (2004). SPSS Uygulamalı Bilimsel Araştırma Yöntemleri. Ankara: Detay Yayinc1lı. Retrieved from http://geka.org.tr/yukleme/Ku\%C5\%9Fadas $\% \mathrm{C} 4 \% \mathrm{~B} 1$.pdf

\section{Copyrights}

Copyright for this article is retained by the author(s), with first publication rights granted to the journal.

This is an open-access article distributed under the terms and conditions of the Creative Commons Attribution license (http://creativecommons.org/licenses/by/3.0/). 